\title{
Blood pressure and lipid profile in young women: the role of anthropometric measurement
}

CDD. 20.ed. 796.033

http://dx.doi.org/10.1590/1807-55092014000400553

\author{
Marcelo Custódio RUBIRA* \\ Ana Paula Fernandes De Angelis RUBIRA** \\ Lucas De Angelis RUBIRA** \\ Milton Carlos Martins LIMA** \\ Roberto Jorge da Silva FRANCO ${ }^{* * * *}$ \\ Fernanda Marciano CONSOLIM-COLOMBO*****
}

${ }^{*}$ Centro de Ciências da Saúde e do Desporto,

Universidade Federal do Acre.

**Faculdade São Lucas - Porto Velho. ${ }^{* * *}$ Faculdade de Medicina, Universidade Estadual Paulista Botucatu.

****Faculdade de Medicina, Universidade de São Paulo.

\begin{abstract}
Body composition has fundamental importance in the quality of life and is a powerful predictor of mortality and morbidity in humans. The identification and monitoring of the amount of body fat have been receiving special attention in aspects related to health promotion, not just for its actions in the prevention and in the control of cardiovascular diseases but also for their induction and association with risk factors, especially in the plasmatic lipid levels and arterial pressure. It was investigated the relationship between body mass index (BMI) and body fat percentage (\%BF) by bioelectrical impedance analysis (BIA) with the blood pressure levels (systolic and diastolic) and serum lipids (TC, HDL-C, LDL-C, VLDL-C, TG). In a group of fifty seven women (aged 18 to 26 years old ), obesity was detected in 5 and 19 women by BMI $\left(\geq 30 \mathrm{~kg} / \mathrm{m}^{2}\right)$ and $\% \mathrm{BF}(\geq 30 \%)$, respectively. $\mathrm{BMI}$ and $\% \mathrm{BF}$ were positively correlated with blood pressure (systolic and diastolic), and highly significant in the obese group by \%BF. Moreover, BMI and $\% \mathrm{BF}$ were significantly correlated with all lipids and lipoprotein fractions VLDL-c and triglyceride, respectively. These results suggest that \%BF is a good indicator of "occult obesity" in subjects with normal body mass index. The associated use of $\mathrm{BMI}$ and \%BF to better evaluate obesity may improve the study of blood pressure levels and serum lipid changes that are commonly associated with obesity.
\end{abstract}

KEY WORDS: Body mass index; Bioelectrical impedance; Obesity; Blood pressure; Lipid.

\section{Introduction}

The prevalence of obesity is increasing worldwide, and obesity is currently regarded as one of the most important public health problems of modern society. Obesity is considered to be a major risk factor for cardiovascular disorders according to the American Heart Association ${ }^{1}$.

In young subjects, the prevalence of obesity more than doubled over the past 15 years. Excessive adiposity in adolescents imposes an even larger risk for future development of cardiovascular diseases, relative to obesity developed in the adult life. Both central and global excessive adiposity may arise as a consequence of abnormality in the lipidic metabolism, being often associated with dyslipidemia and arterial hypertension ${ }^{2}$.
Indeed, according to the National Institute of Health, obesity should be seen as a chronic degenerative disorder, since it increases the risks of early death even when it is minor. According to the National Institute of Health, risks are significantly elevated even for increased weight as low as from 2.3 to $4.5 \mathrm{~kg}$ above normal limits ${ }^{3}$.

Body composition has fundamental importance in the quality of life ${ }^{4}$ and is a powerful predictor of mortality and morbidity in humans ${ }^{5}$. The identification and monitoring of the amount of body fat have been receiving special attention in aspects related to health promotion, not just for its actions in the prevention and in the control of cardiovascular diseases but also for their induction 
and association with risk factors, especially in the plasmatic lipid levels and arterial pressure ${ }^{6-7}$.

Variations in body fat content and regional fat distribution, whatever their origin is (genetic, acquired), seem to be potential candidates to explain, at least in part, the changes in cardiovascular risk profile. The excess accumulation body fat, in the central part of body and/or total body fat ${ }^{8}$, is a sign of abnormal lipid metabolism and is frequently associated with dyslipidemia and arterial hypertension ${ }^{6,9}$.

The sympathetic nervous system seems to be activated in obesity ${ }^{10}$. However, this increased tonus is not homogenous for all tissues and organs. While the sympathetic activation is demonstrated at the level of the kidneys and skeletal muscles, cardiac sympathetic activity does not seem to be increased ${ }^{11}$. However, cardiac autonomic disturbances such as decreased vagal tonus, with or without sympathetic activation, are documented in obesity ${ }^{12}$.

\section{Method}

\section{Subjects}

Fifty seven white women, physiotherapy students, ranging in age from 18 to 26 years old were studied. The sample consisted of subjects without any medication, especially diet and known disease.

All participants signed an informed consent approved by the Ethics Committee.

\section{Anthropometric measures}

Body mass index (BMI) was calculated as weight/ height ${ }^{216}$. Bioeletric resistance was measured with an Bioelectrical impedance analyzer (BIA-RJL Systems Model 101) using a standard tetrapolar technique according to the manufacturer's instructions and calibrated weekly with a $500 \mathrm{Ohm}$ resistor. BIA is based on the principle that impedance to an electrical flow of an applied current is related to the volume of the conductor (the human body) and the square of the conductor's length (height). BIA results are based on the greater electrolyte content of the free mass and its greater conductivity of electricity compared with fat tissue. Bioelectrical impedance measurements were taken on the right side of the body with the subjects lying supine on a nonconductive surface in a room with normal ambient temperature. The skin was cleaned at the electrode sites with an alcohol pad.
The most common estimate of body composition in populations has been the body mass index, which was actually developed as a measure of weight /height ${ }^{2}$ and not as an index of obesity ${ }^{13}$. Its importance is due to values around $30 \mathrm{~kg} / \mathrm{m}^{2}$ (obese subjects) to correlate with high incidence of diseases, mainly arterial hypertension, lipid disorders - high cholesterol, triglyceride and cardiovascular diseases ${ }^{14}$. The bioelectrical impedance analysis (BIA) is an appropriate method for monitoring the body fat and superior to body mass index as measurement of the body composition ${ }^{15}$ due to measure the content of fat into corporal mass.

In reason of the importance of recognizing subjects with high risk develop arterial hypertension and other metabolic disorders, and the operational simplicity of the anthropometric methods, the present work has an objective to correlate anthropometric index with the blood pressure and serum lipids.

The sensor (proximal) electrodes were placed on the dorsal surface of the wrist so that the upper border of the electrode bisected the head of the ulna and on the dorsal surface of the ankle so that the upper border of the electrode bisected the medial and lateral malleoli. The source (distal) electrodes were placed at the base of the second metacarpal-phalangeal and metatarsalphalangeal joints of the hand and foot . The researcher made certain that there were at least $5 \mathrm{~cm}$ between the proximal and distal electrode. The lead wires were then attached to the appropriate electrodes. The tester made certain that the subject's legs and arms were abducted approximately $45^{\circ}$ to each other. There was no contact between the thighs and between the arms and the trunk. Duplicated measurements were taken, and the average of the two measurements was used for calculating body fat percentage $(\% \mathrm{BF})^{15}$. If the $\% \mathrm{BF}$ was off by more than $0.5 \%$, the test was repeated until two readings were within $0.5 \%$. The subjects were instructed not to ingest alcohol or caffeine 24 hours or exercise 12 hours before testing. Women were measured within 1 week after their menstrual cycles.

\section{Hemodynamic measures}

Arterial blood pressure was measured with a mercury sphygmomanometer, using the disappearance of Korotkoff sounds (phase V) as 
a criteria for the determination of diastolic blood pressure. Arterial blood pressure was measured by a single observer in the right arm of seated participants. A rigorously standardized protocol was followed in which the participants were seated at least 10 minutes prior to the first measurement and at least 2 minutes elapsed between three repeat measurements. Cuff size was based on arm dimensions (cuff were long enough to completely encircle the arm and wide enough to cover two-thirds the length of the upper arm). The values used in the present analysis are the means of all measurements realized ${ }^{17}$.

\section{Serum lipids analysis}

In all subjects $10 \mathrm{ml}$ venous blood was collected at 8:00 to 9:00 a.m. after an overnight fast. After collection of serum by centrifugation, serum total cholesterol (TC), high density lipoprotein cholesterol

\section{Results}

The subjects characteristic is summarized in TABLE 1 . The mean systolic $(109 \pm 9 \mathrm{mmHg})$ and diastolic $(71 \pm 7 \mathrm{mmHg}$ ) blood pressure were in normal limits for almost all subjects, and only 5 subjects had values in hypertensive level (above $140 / 90 \mathrm{mmHg}$ in accordance with the classification of the Joint National Committee) ${ }^{17}$. The mean lipid profile was in normal level for almost all subjects. The total cholesterol level ranged from 123 to $271 \mathrm{mg} / \mathrm{dl}$, and a total of 19 women with levels $\geq 200 \mathrm{mg} / \mathrm{dl}$, considered high level in accordance to the classification of the National Cholesterol Education Program ${ }^{19}$.

The mean value for BMI was considered normal 22 $\pm 4 \mathrm{~kg} / \mathrm{m}^{2}$ with a range from 16.1 to $36 \mathrm{~kg} / \mathrm{m}^{2}$. The mean \% BF (28 $\pm 6 \%)$ by bioelectrical impedance analysis (BIA) was above of value considered normal $(26 \%$ of fat) with a range from 14 to 43 $\%$ body fat. The majority of subjects analyzed by BMI were nonobese with a frequency distribution demonstrating that 49 subject had values below 25 $\mathrm{kg} / \mathrm{m}^{2}$ (normal), 3 subject had values between 25 to $29 \mathrm{~kg} / \mathrm{m}^{2}$ (overweight) and 5 subject had values $\geq 30$ $\mathrm{kg} / \mathrm{m}^{2}$ (obese) in accordance to the classification of the Consensus Latin American of Obesity ${ }^{20}$ (TABLE 2).

The frequency distribution of $\% \mathrm{BF}$ by BIA demonstrated that 25 subjects had values below $26 \%$ (normal), 13 had values from 26 to $29 \%$
(HDL-c), low density lipoprotein cholesterol (LDL-c), very low density lipoprotein cholesterol (VLDL-c) and triglyceride (TG) were analyzed.

The total cholesterol level was measured by CHOD-PAP method, LDL-c by polyvinyl sulfate. The HDL-c was separated with the phosphotungstic acid/magnesium chloride method. Triglyceride e VLDL-c were measured by the enzymatic colorimetric test (GOP-PAP method) ${ }^{18}$.

\section{Statistical analysis}

The statistical analysis was performed using software SAEG (System Analysis Statistical Genetic). The 0.05 alpha level was adopted as criteria for statistical significance. Descriptive statistics (means and standard deviations) were calculated for all variables. Pearson's correlation coefficients were used to show the relationship between variables.

(overweight) and 19 had values $\geq 30 \%$ (obese) in accordance with the works of HALPERN ${ }^{21}$; GUEDEs ${ }^{22}$ and $\mathrm{ENZI}^{23}$ (TABLE 2).

It is important to note that 49 subjects had values into normal limits $\left(<25 \mathrm{~kg} / \mathrm{m}^{2}\right)$ when analyzed by BMI. However, the BIA detected 24 subjects with lipids metabolism disorders overweight (10 subjects) and obesity (14 subjects).

The Pearson's correlation between blood pressure and anthropometric measurements are given in TABLE 3. Clearly, the values of BMI of all subjects correlated with systolic and diastolic blood pressure. When subgroups of subjects with different levels of BMI were analyzed, we can demonstrate that there were no correlation between the BMI and blood pressure values in the normal subgroup $\left(25 \mathrm{~kg} / \mathrm{m}^{2}\right)$, only in the overweight and obese group.

The \%BF by BIA method tended to be significantly correlated with systolic and diastolic blood pressure when all subjects were analyzed. In analysis similar to that done in BMI, the \% BF by BIA method in the normal subgroup there was no correlation, and in obesity group ( $\% \mathrm{BF} \geq 30 \%)$ there was a stronger correlation with blood pressure.

It's important to note that, in the subgroup of the obese the \%BF by BIA established better correlation with the blood pressure while BMI just was related with systolic pressure. 
The correlation between BMI and \%BF all subjects were significant with all lipids and lipoprotein fractions, TC, VLDL-c and TG, respectively. The BMI subgroup analysis demonstrates a loss of correlation for all different groups, including the $\geq 30 \mathrm{~kg} / \mathrm{m}^{2}$ group. Differently, the $\% \mathrm{BF}$ by BIA demonstrate a loss correlation in normal and overweight group but obese subjects was highly significant with lipoprotein fractions, HDL-c, TG,VLDL-c (TABLE 4).

So, it is relevant to note that 19 subjects detected by BIA as obese were considered normal by BMI. This subgroup was called in the literature as "occult obese $^{24}$. We verified this subgroup (occult obese) had a stronger correlation with a blood pressure and lipoprotein fractions HDL-c, TG, VLDL-c.

TABLE 1 - Characteristics of subjects studied.

$\mathrm{BMI}=$ indicated body mass index;

$\mathrm{SBP}=$ systolic blood pressure;

$\mathrm{DBP}=$ diastolic blood pressure;

$\mathrm{TC}=$ total cholesterol;

$\mathrm{HDL}-\mathrm{C}=$ high density lipoprotein cholesterol; LDL-C = low density lipoprotein cholesterol; VLDL-c = very low density lipoprotein cholesterol;

$\mathrm{TG}=$ triglyceride and $\% \mathrm{BF}$, body fat percentage. Values are represented as mean (SD).

\begin{tabular}{lc}
\hline Variables & Women $(\mathbf{n}=\mathbf{5 7})$ \\
\hline Age, years & $21.6 \pm 1.4$ \\
SBP, mmHg & $109.6 \pm 9.7$ \\
DBP, $\mathrm{mmHg}$ & $71.5 \pm 7.6$ \\
$\mathrm{TC}, \mathrm{mg} / \mathrm{dl}$ & $182.8 \pm 35.8$ \\
$\mathrm{HDL}-\mathrm{C}, \mathrm{mg} / \mathrm{dl}$ & $60.7 \pm 12.5$ \\
$\mathrm{LDL}-\mathrm{c}, \mathrm{mg} / \mathrm{dl}$ & $103.9 \pm 34.6$ \\
VLDL, $\mathrm{mg} / \mathrm{dl}$ & $18.2 \pm 8.5$ \\
$\mathrm{TG}, \mathrm{mg} / \mathrm{dl}$ & $92.8 \pm 42.4$ \\
$\mathrm{BMI}, \mathrm{kg} / \mathrm{m}^{2}$ & $22.2 \pm 4.0$ \\
$\% \mathrm{BF}, \%$ & $28.0 \pm 6.9$ \\
\hline
\end{tabular}

TABLE 2 - Frequency distribution of BMI and \%BF (BIA) in accordance with the classification of the Consensus Latin American of obesity and with the works of Halpern; Guedes, Enzi.

\begin{tabular}{lclc}
\hline BMI & Subjects & \%BF & Subjects \\
\hline$<25 \mathrm{~kg} / \mathrm{m}^{2}$ & 49 & $<26 \%$ & 25 \\
$25 \mathrm{a} 29 \mathrm{~kg} / \mathrm{m}^{2}$ & 3 & 26 at $29 \%$ & 13 \\
$\geq 30 \mathrm{~kg} / \mathrm{m}^{2}$ & 5 & $\geq 30 \%$ & 19 \\
\hline
\end{tabular}

TABLE 3 - Pearson's correlation coefficients between anthropometric measurement and blood pressure.

\begin{tabular}{|c|c|c|c|}
\hline \multirow{9}{*}{$\begin{array}{l}{ }^{*} \mathrm{p}<0.05 ; \\
{ }^{* *} \mathrm{p}<0.01 ; \\
{ }^{* * *} \mathrm{p}<0.001 ; \\
\mathrm{BMI}=\text { indicated body } \\
\text { mass index; } \\
\% \mathrm{BF}=\text { body fat } \\
\text { percentage; } \\
\mathrm{SBP}=\text { systolic blood } \\
\text { pressure; } \\
\text { DBP = diastolic blood } \\
\text { pressure. }\end{array}$} & Anthropometric measurements & SBP & DBP \\
\hline & $\begin{array}{l}\text { BMI kg/m } \mathrm{m}^{2} \\
(\mathrm{n}=57)\end{array}$ & $0.41^{* * *}$ & $0.31^{* *}$ \\
\hline & $\begin{array}{l}\mathrm{BMI}<25 \mathrm{~kg} / \mathrm{m}^{2} \\
(\mathrm{n}=49)\end{array}$ & 0.18 & 0.14 \\
\hline & $\begin{array}{l}\text { BMI } 25 \text { a } 29 \mathrm{~kg} / \mathrm{m}^{2} \\
(\mathrm{n}=3)\end{array}$ & 0.30 & $0.98^{*}$ \\
\hline & $\begin{array}{l}\mathrm{BMI} \geq 30 \mathrm{~kg} / \mathrm{m}^{2} \\
(\mathrm{n}=5)\end{array}$ & $0.82^{*}$ & 0.17 \\
\hline & $\begin{array}{l}\% \mathrm{BF} \\
(\mathrm{n}=57)\end{array}$ & $0.27^{*}$ & $0.27^{*}$ \\
\hline & $\begin{array}{l}\% \mathrm{BF}<26 \% \\
(\mathrm{n}=25)\end{array}$ & 0.01 & 0.09 \\
\hline & $\begin{array}{l}\% \text { BF } 26 \text { at } 29 \% \\
(\mathrm{n}=13)\end{array}$ & 0.10 & 0.17 \\
\hline & $\begin{array}{l}\% \mathrm{BF}(30 \%) \\
(\mathrm{n}=19)\end{array}$ & $0.67^{* * *}$ & $0.62^{* *}$ \\
\hline
\end{tabular}

556 • Rev Bras Educ Fís Esporte, (São Paulo) 2014 Out-Dez; 28(4):553-60 
TABLE 4 - Pearson's correlation coefficients between anthropometric measurements and serum lipids.

\begin{tabular}{|c|c|c|c|c|c|}
\hline \multirow{2}{*}{ Anthropometric measurements } & \multicolumn{5}{|c|}{ Serum lipids } \\
\hline & TC & LDL-C & HDL-C & VLDL-C & TG \\
\hline $\begin{array}{l}\text { BMI kg/m } \mathrm{m}^{2} \\
(\mathrm{n}=57)\end{array}$ & $0.28^{*}$ & $0.31^{* *}$ & $-0.36^{* *}$ & $0.43^{* * *}$ & $0.43^{* * *}$ \\
\hline $\begin{array}{l}\mathrm{BMI}<25 \mathrm{~kg} / \mathrm{m}^{2} \\
(\mathrm{n}=49)\end{array}$ & 0.11 & 0.19 & -0.19 & 0.02 & 0.02 \\
\hline $\begin{array}{l}\text { BMI } 25 \text { a } 29 \mathrm{~kg} / \mathrm{m}^{2} \\
(\mathrm{n}=3)\end{array}$ & 0.01 & 0.78 & -0.47 & 0.96 & 0.96 \\
\hline $\begin{array}{l}\mathrm{BMI} \geq 30 \mathrm{~kg} / \mathrm{m}^{2} \\
(\mathrm{n}=5)\end{array}$ & 0.78 & 0.78 & -0.21 & 0.41 & 0.42 \\
\hline $\begin{array}{l}\% \mathrm{BF} \\
(\mathrm{n}=57)\end{array}$ & $0.23^{*}$ & 0.21 & -0.15 & $0.35^{* *}$ & $0.36^{* *}$ \\
\hline $\begin{array}{l}\% \mathrm{BF}<26 \% \\
(\mathrm{n}=25)\end{array}$ & 0.11 & 0.11 & -0.02 & 0.03 & 0.04 \\
\hline $\begin{array}{l}\% \text { BF } 26 \text { at } 29 \% \\
(n=13)\end{array}$ & $0.53^{*}$ & 0.39 & -0.15 & 0.37 & 0.35 \\
\hline $\begin{array}{l}\% B F(30 \%) \\
(n=19)\end{array}$ & 0.09 & 0.08 & $-0.42^{*}$ & $0.56^{* *}$ & $0.57^{* *}$ \\
\hline
\end{tabular}

${ }^{*} p<0.05$

${ }^{* *} p<0.01$

${ }^{* * *} p<0.001$

$\mathrm{BMI}=$ indicated body mass index;

$\% B F=$ body fat percentage;

TC = total cholesterol; HDL-C = high density lipoprotein cholesterol;

LDL-C = low density lipoprotein cholesterol; VLDL-C = very low density lipoprotein cholesterol and ; $\mathrm{TG}=$ Triglyceride .

\section{Discussion}

The importance of conducting studies in young subjects is demonstrated by the increasing prevalence of obesity in this population, and by the fact that minor excess fat developed at young ages imposes an even higher vascular risk than the onset of obesity in adulthoo ${ }^{25}$.

The main results of our study are the demonstration that there is a significant group of young women considered "normal" by BMI were already "occult obese" when evaluated by the BIA method ${ }^{26}$. Furthermore, in this group there was a strong correlation between $\% \mathrm{BF}$ with blood pressure and serum lipid profile.

Although the BMI is easy to use in population studies, it is not precise as a predictor of cardiovascular risk, since it may either over or underestimates the real proportion of fat. Additionally, BMI does not distinguish between fat weight and non-fat weight and does not allow inferences about the corporal distribution of $\mathrm{fat}^{24}$.

The importance of these results is that the regular use of BMI alone in analysis of body composition is not enough, there is a necessity of a more specific method to improve the detection of lipid metabolic alterations, search as BIA. The "occult obesity" group was already suggested by FUKUI ${ }^{27}$ when he studied more than 2,955 subjects. Although our group is small, we could find similar results to that $\% \mathrm{BF}$ by
BIA is an appropriate index that better reflects serum lipids and blood pressure in "occult obesity", and may be a superior body mass index in these group.

We found that a significant proportion of subjects in our study had elevated fat proportion, while been classified as normal weight by the BMI. Based on the important recognition that excessive adiposity is linked to cardiovascular and metabolic disorders, anthropometric methods are recommended because of their accuracy and simplicity.

Anthropometric methods are of utility in several domains including epidemiological vigilance, scientific investigation, individual and social health screenings, and should be particularly recommended for individuals that are not overweight or obese according to the $\mathrm{BMI}^{8}$.

Indeed, when more rigorous methods are used to measure the proportion of fat, it becomes patent that is faith itself and not absolute weight that increases cardiovascular risk. This is true not only for an important increase in fat proportion, but also for minor increases ${ }^{28}$. Indeed the importance of estimating the proportion of fat in predicting coronary diseases is supported by the work of Rimm and colleagues ${ }^{29}$.

Another important observation is that the associated use of BMI and \%BF is best for evaluating lipid alterations and the obesity diagnoses, and it's correlation with blood pressure and serum lipid levels. The 
importance of body composition in the quality of life is well established. An inappropriate body composition can take many disorders in the human organism, for example the obesity and the malnutrition both associated with the development of several diseases ${ }^{30}$.

Obesity ( $\geq 30 \% \mathrm{BMI})$, excess accumulation of body fat, is a sign of abnormal lipid metabolism, and is an important predictor for hypertension, coronary heart disease, diabetes mellitus, hepato biliary disease ${ }^{16}$ and frequently is associated with arterial hypertension and dyslipidaemia (high serum TG and low serum HDL-C rather than high serum TC and LDL-C) $)^{8}$.

Obesity is not a homogeneous disorder. In a subgroup of obese individuals, the sympathetic tonus is increased to key organs, including the kidney, muscles and peripheral vessels. Evidence for increased sympathetic tonus of the heart is less strong, especially in individuals without hypertension ${ }^{11}$.

Obese individuals are at increased risk of developing cardiac arrhythmia and sudden death when compared to normal weight individual ${ }^{31}$.

In healthy animals, obesity induced by excessive feeding is associated with sympathetic activation and hypertension. Sympathetic activation is precociously induced by overfeeding, and is reversed by weight loss. Modification in the sympathetic system induced by overfeeding seems to precede alterations in the renin-angiotensin system ${ }^{32}$.

Subjects with lower levels of fat (overweight) show the same risks of heart disease, arterial hypertension and metabolic disorders when compare to that subjects with high and moderate percentage of fat body ${ }^{3}$.

The association of blood pressure with body weight could be due to the increased total body mass or some special underlying relationship between blood pressure and body fat ${ }^{33}$.

Our study and others studies as FukUI ${ }^{27}$ and NAGAYA $^{24}$ suggested the existence of a subgroup of subjects with "occult obesity" that are not aware for their lipid alterations and blood pressure. Although the impact of this alteration in cardiac morbidity has not been studied yet, we can hypothetically suggest that this group could have a worth prognosis than people with normal lipid composition. More prospective studies with larger population with "occult obesity" are necessary to answer this point.

It is important to consider anthropometric measurements beyond the BMI. While we know its advantages in population studies, it does not distinguish body composition, and may underestimate or overestimate the actual percentage of fat, keeping us from strongly correlate with blood pressure, serum lipids and cardiovascular risk. A more thorough evaluation and careful body composition is required for prevention and health promotion.

The increased body fat was positively related to disorders in lipid metabolism and blood pressure elevation. However, further studies are needed to thoroughly clarify and define these relationships.

\section{Resumo}

Pressão arterial e perfil lipídico em mulheres jovens: o papel da avaliação antropométrica

Composição corporal tem importância fundamental para a qualidade de vida e é um forte preditor de mortalidade e morbidade nos seres humanos. A identificação e o monitoramento da quantidade de gordura corporal têm recebido atenção especial no que se refere aos aspectos relacionados com a promoção da saúde, não apenas de suas ações na prevenção e no controle das doenças cardiovasculares, mas também pela sua associação com fatores de risco, especialmente em niveis de lipídeos plasmáticos e da pressão arterial. Foi investigado a relação entre o índice de massa corporal (IMC) e percentual de gordura corporal (\% GC) pela bioimpedância elétrica (BIA), com os níveis de pressão arterial (sistólica e diastólica) e lipídeos séricos (CT, HDL-c, LDL-c, VLDL-C, TG). Em um grupo de 57 mulheres (com idades entre 18 e 26 anos de idade), a obesidade foi detectada em cinco e 19 mulheres, IMC ( $\left.\geq 30 \mathrm{~kg} / \mathrm{m}^{2}\right)$ e $\%$ $\mathrm{BF}(\geq 30 \%)$, respectivamente. IMC e $\% \mathrm{GC}$ foram positivamente correlacionados com a pressão arterial (sistólica e diastólica), e altamente significativos no grupo dos obesos pelo \% GC. Além disso, o IMC e \% GC foram significativamente correlacionados com todos os lipídios e frações de lipoproteínas VLDL-C e triglicérides, respectivamente. Estes resultados sugerem que o \% GC é um bom indicador de "obesidade oculta" em indivíduos com índice de massa corporal normal. Que o uso associado de IMC e \% GC para 
melhor avaliar a obesidade pode melhorar o estudo dos níveis de pressão arterial e alterações de lipídios que é geralmente associada à obesidade.

PalavRas-chave: Índice de massa corporal; Bioimpedância elétrica; Obesidade; Pressão arterial; Lipídios.

\section{References}

1. Carneiro G, Faria AN, Ribeiro Filho FF, et al. Influence of body fat distribution on the prevalence of arterial hypertension and other cardiovascular risk factors in obese patients. Rev Assoc Med Bras. 2003;49:306-11.

2. Hall JE, Crook ED, Jones DW, Wofford MR, Dubbert PM. Mechanisms of obesity-associated cardiovascular and renal disease. Am J Med Sci. 2002;324:127-37.

3. NIH. National Institutes of Health. Health implications of obesity: National Institutes of Health Consensus Development Conference Statement. Ann Intern Med.1985;103:1073-77.

4. Rademacher ER, Jacobs Junior DR, Moran A, Steinberger J, Prineas RJ, Sinaiko A. Relation of blood pressure and body mass index during childhood to cardiovascular risk factor levels in young adults. J Hypertens. 2009;27:1766-74.

5. Katzmarzyk PT, Janssen I, Ardern CI. Physical inactivity, excess adiposity and premature mortality. Obes Rev. 2003;4:257-90.

6. Sarno F, Monteiro CA. Importância relativa do índice de massa corporal e da circunferência abdominal na predição da hipertensão arterial. Rev Saude Publica. 2007;41:788-96.

7. Souza MGB, Rivera IR, Silva MAM, Carvalho ACC. Relação da obesidade com a pressão arterial elevada em crianças e adolescentes. Arq Bras Cardiol. 2010;94:714-9.

8. Huang XB, Hu R, Liu JL, et al. [Relationship between body mass index, waist circumference and blood pressure among 5246 residents in Chongqing area]. Zhonghua Xin Xue Guan Bing Za Zhi. 2007;35:655-8.

9. Tu YK, Summers LK, Burley V, et al. Trends in the association between blood pressure and obesity in a Taiwanese population between 1996 and 2006. J Hum Hypertens. 2011;25:88-97.

10. Esler M, Rumantir M, Kaye D, Lambert G. The sympathetic neurobiology of essential hypertension: disparate influences of obesity, stress, and noradrenaline transporter dysfunction? Am J Hypertens. 2001;14:139S-46S.

11. Grassi G, Seravalle G, Dell'Oro R, Turri C, Bolla GB, Mancia G. Adrenergic and reflex abnormalities in obesity-related hypertension. Hypertension. 2000;36:538-42.

12. Quilliot D, Fluckiger L, Zannad F, Drouin P, Ziegler O. Impaired autonomic control of heart rate and blood pressure in obesity: role of age and of insulin-resistance. Clin Auton Res. 2001;11:79-86.

13. Garrido-Chamorro RP, Sirvent-Belando JE, Gonzalez-Lorenzo M, Martin-Carratala ML, Roche E. Correlation between body mass index and body composition in elite athletes. J Sports Med Phys Fitness. 2009;49:278-84.

14. Stenholm S, Koster A, Alley DE, et al. Joint association of obesity and metabolic syndrome with incident mobility limitation in older men and women-results from the health, aging, and body composition study. J Gerontol A Biol Sci Med Sci. 2009;65:84-92.

15. Amani R. Comparison between bioelectrical impedance analysis and body mass index methods in determination of obesity prevalence in Ahvazi women. Eur J Clin Nutr. 2007;61:478-82.

16. Guimaraes IC, de Almeida AM, Santos AS, Barbosa DB, Guimaraes AC. Blood pressure: effect of body mass index and of waist circumference on adolescents. Arq Bras Cardiol. 2008;90:393-9.

17. JNC. Joint National Committee. The sixth report of the Joint National Committee on prevention, detection, evaluation, and treatment of high blood pressure. Arch Intern Med1997;157:2413-46.

18. Fedder DO, Koro CE, L'Italien GJ. New National Cholesterol Education Program III guidelines for primary prevention lipid-lowering drug therapy: projected impact on the size, sex, and age distribution of the treatment-eligible population. Circulation. 2002;105:152-6.

19. NCEP. National Cholesterol Education Program. Third report of the National Cholesterol Education Program (NCEP) expert panel on detection, evaluation, and treatment of high blood cholesterol in adults (Adult Treatment Panel III) final report. Circulation. 2002;106:3143-421.

20. Consensus-Latin-American-Obsety. Classification of the Consensus Latin American of Obesity. Arq Bras Endocrinol Metabol. 1999;43:22-6. 
21. Halpern A. Obesidade: mitos e verdades. 2a ed. São Paulo: Contexto; 1997.

22. Guedes DP, Guedes JE. Distribuição de gordura corporal, pressão arterial e níveis de lipídios-lipoproteínas plasmáticas. Arq Bras Cardiol. 1998;70:93-8.

23. Enzi G, Gasparo M, Biondetti PR, Fiore D, Semisa M, Zurlo F. Subcutaneous and visceral fat distribution according to sex, age, and overweight, evaluated by computed tomography. Am J Clin Nutr. 1986;44:739-46.

24. Nagaya T, Yoshida H, Takahashi H, Matsuda Y, Kawai M. Body mass index (weight/height ${ }^{2}$ ) or percentage body fat by bioelectrical impedance analysis: which variable better reflects serum lipid profile? Int J Obes Relat Metab Disord. 1999;23:771-4.

25. Riva P, Martini G, Rabbia F, et al. Obesity and autonomic function in adolescence. Clin Exp Hypertens. 2001;23:57-67.

26. Willett K, Jiang R, Lenart E, Spiegelman D, Willett W. Comparison of bioelectrical impedance and BMI in predicting obesity-related medical conditions. Obesity (Silver Spring). 2006;14:480-90.

27. Fukui A. [Relationship between obesity, total plasma cholesterol and blood pressure in male adults]. Sangyo Eiseigaku Zasshi. 2000;42:119-24.

28. Singh RB, Niaz MA, Beegom R, Wander GS, Thakur AS, Rissam HS. Body fat percent by bioelectrical impedance analysis and risk of coronary artery disease among urban men with low rates of obesity: the Indian paradox. J Am Coll Nutr. 1999;18:268-73.

29. Rimm EB, Stampfer MJ, Giovannucci E, et al. Body size and fat distribution as predictors of coronary heart disease among middle-aged and older US men. Am J Epidemiol. 1995;141:1117-27.

30. Burgos MS, Reuter CP, Burgos LT, et al. Uma análise entre índices pressóricos, obesidade e capacidade cardiorrespiratória em escolares. Arq Bras Cardiol. 2010;94:788-93.

31. Hirsch J, Leibel RL, Mackintosh R, Aguirre A. Heart rate variability as a measure of autonomic function during weight change in humans. Am J Physiol. 1991;261:R1418-23.

32. Cole CR, Blackstone EH, Pashkow FJ, Snader CE, Lauer MS. Heart-rate recovery immediately after exercise as a predictor of mortality. N Engl J Med. 1999;341:1351-7.

33. Redon J, Cea-Calvo L, Moreno B, et al. Independent impact of obesity and fat distribution in hypertension prevalence and control in the elderly. J Hypertens. 2008;26:1757-64.

Marcelo Custódio Rubira

R. Brasília, 3062 - apto. 102 - Bairro São Cristovão 76804-070 - Porto Velho - AC - BRASIL

Recebido para publicação: 05/04/2014 e-mail: rubiramc@terra.com.br 